\title{
The structure of a mobile provider network with network functions virtualization
}

\author{
Skulysh Mariia, Romanov Oleksandr \\ National Technical University of Ukraine \\ «Ihor Sikorsky Kyiv Polytechnic Institute» \\ Kyiv, Ukraine
}

\begin{abstract}
Ensuring quality of service for end users of communication networks depends on quality control at all stages of end-to-end service delivery. Today, due to the dynamically changing structure of the services provided to end users, constantly changing requirements to the quality of service indicators and growth of traffic volumes increases, there is a need for highly scalable communication systems, which could meet the needs of end users. This paper describes methods of improving the quality of service of hybrid telecommunication networks, which involve the systematic application of methods for monitoring and managing the process of formation of flows for maintenance and allocation of service resources.
\end{abstract}

Keywords - NFV, VeCME, VBS, VeEPC, LTE, 5G

\section{INTRODUCTION}

Today the work of the telecommunication network is closely related to the operation of computing systems. In the Recommendation ITU-T M.3371 of October 2016, the term "hybrid telecommunications service" which means the service consists of components of telecommunications and cloud services appears. The network of a mobile provider consists of radio access network, a local area network and a provider core network.

With the advent of cloud computing paradigm, the possibilities in the organization of the service process in telecommunication systems are expanding. In the ETSI GS NFV 001 v.1.1.1 (10/2013), the main architectural solutions are presented. Instead of complex hardware solutions, they propose methods for network functions virtualization for different parts of the network, which will allow flexibly adjusting of service computing resources.

As a result, there is a need for new methods of monitoring and managing the quality of service that would take into account the specifics of the service process both in the telecommunication system and in the computing service environment of hybrid telecommunications services.

The main objective of this scientific research is to improve the quality of servicing for hybrid telecommunication services, through the systematic application of methods of monitoring and managing flows formation process for maintenance and resources allocation. For achieving this goal, the following tasks are solved:

1. To investigate the achievements of the scientific community in the field of monitoring and ensuring the quality of service of telecommunication hybrid services, to reveal patterns, trends and features.
2. To develop a model of servicing the hybrid service in a heterogeneous telecommunication environment.

3. To develop methods for maintaining the quality of service in the provider radio access networks.

4. To develop methods for managing the quality of service in the provider local networks, including the boundary of the local network.

5. To develop a model and methods for the operation of the provider core in a heterogeneous cloud infrastructure.

6. To develop a model of service organization in provider charging system.

To realize the main problems of communication provider, the following factors and trends must be taken into account:

1. The growth of traffic volumes in an exponential progression every year.

2. Multiservice flow requires differentiated services, different requirements for quality indicators, different requirements for the organization of the transfer process, accounting and tariffing of traffic.

3. In order to guarantee the declared quality of service indicators, the provider must constantly monitor the quality of customer service and respond in time to a decline of quality indicators.

That is, the provider monitoring system collects a large amount of information about the quality of the transmission of each service requested by the subscriber. In addition, the provider telecommunications subsystems are monitored; the workload and number of service failures are accounted and much more.

\section{IMPLEMENTATION OF THE PROPOSED METHODS}

Today there are many mechanisms for adaptive response to a decline in the quality of service. The following groups of mechanisms are:

1. Monitoring of queue service performance in communication nodes.

2. Monitoring of network load.

3. Queuing management for differentiated servicing of multi-service flows.

4. Monitoring of subscriber data flows parameters. 
5. Methods of feedback - mechanisms to prevent data sources about possible overloads of the chosen direction of communication.

6. Methods of engineering traffic for scheduling an equable load of network resources.

According to ETSI GS NFV 001 v.1.1.1 (10/2013), all computational functions accompanying the transfer process will be performed in data centers with cloud infrastructure. Virtualization of the base station will ensure the reduction of power consumption, associated with dynamic allocation of resources and traffic load balancing. In addition to virtual base stations, radio access networks with cloud-based organization of resources (Cloud-RAN) is required to create a base frequency processing resource (BaseBand Unit - BBU) for combining various resources into a centralized virtual environment.

According to the specification, virtualization of network functions is proposed for a router located on the border of the provider local network. A router performs thread classification functions, routing control and providing firewall protection.

The organization of virtual base stations and VeCPE presupposes the existence of a data center close to the base stations and to each output from the local network. That is, the functioning of the provider network is a geographically distributed network of data centers with communication channels delivered primary information of mobile subscribers to each of them. This network requires conversion at the lowest level, which means the signal requires recognition and decoding at higher levels of MAC, RLC, RRC, and PDCP.

The specification is also proposes virtualization of the provider core.

Thus, it is obvious that most of the provider network processes occurs in the data centers. Communication networks are only a means of delivering information messages. In the conditions of distribution of program-controlled routers, we have the network structure shown in Fig. 1.

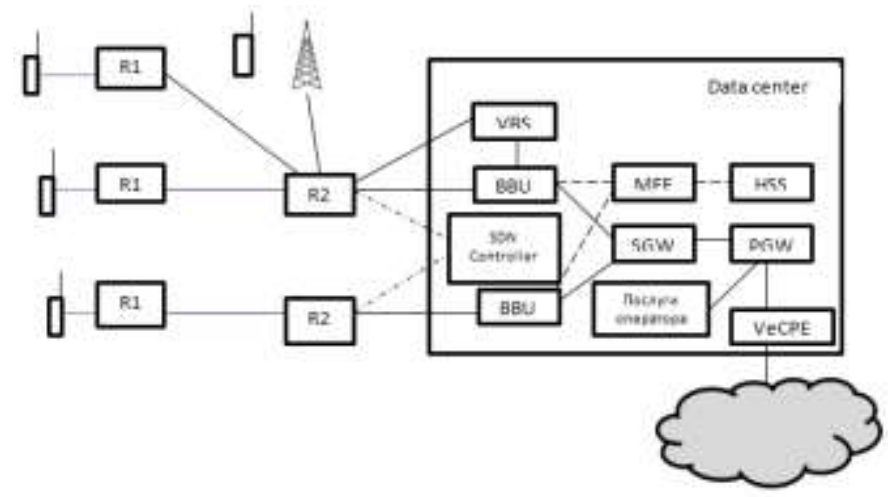

Fig.1 Provider core network structure using softwarecontrolled routers

For a long time, the functioning of heterogeneous solutions for networks will coexist with the non-virtualized networks of the telecommunications operator that operate today.
Fig. 1 shows how the mobile subscriber communicates with the R1 transponder, which converts the radio signal to optical, and then the signal reaches the $\mathrm{R} 2$ transponder managed by the SDN controller, which is also situated in the data center. Getting into the data center, the signal is processed by the virtual base station. Further, according to LTE technology, the flow is sent to the operator's core for further processing.

Підсистема BBU (блок формування моділюючих сигналів) основана на технології программноконфигурованих мереж/віртуалізації функционування метері, це система, яка підтрмує роботу не лише роботу віртуальних базових станцій, але працює і для гібридних рішень 2G/3G/4G/Pre5G.

Servicing in the core determines the further direction of the data channels. If the stream is directed to the provider internal network, then, it is immediately sent for service to the corresponding virtual base station in the data center, and is then forwarded to the subscriber through the transponders R2 and $\mathrm{R} 1$. If its purpose lies beyond the boundaries of the provider local area network, then the stream is directed to the virtual router of the local network boundary, which is located immediately in the data center. In addition, after the servicing flow is sent to external networks.

This kind of network will have next-generation networks. However, if you look at the data center element, it becomes clear that it combines a group of data centers connected through a secure network into a single logical service space of the virtualized network functions. Moreover, the provision of high-quality service to end users, essentially depends on the organization of processes in such a heterogeneous data center based on the concept of cloud computing.

According to the recommendation of ITU-T Y.3500, cloud computing is the paradigm of providing network access to a scalable and flexible set of shared physical and virtual resources. It also implies the provision and administration of resources based on on-demand self-service.

Telecommunication structure of the described data center in which the group of functional blocks shown in fig. 1 are servicing is shown in fig. 2. It describes transport network and connected data centers, forming a single virtualized space.

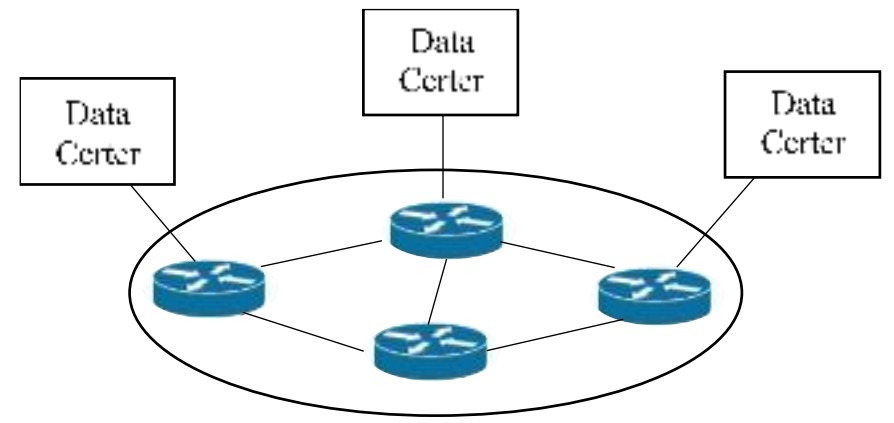

Fig. 2 The structure of the data center

ITU-T Recommendation Y.3511 provides a definition for such a complex group system of data centers as multi-cloud computing - a paradigm for interaction between two or more providers of cloud services. 
The ITU-T Recommendation Y.3520 presented the conceptual architecture of the multi-cloud and multi-platform cloud services management presented in fig. 3 [1]

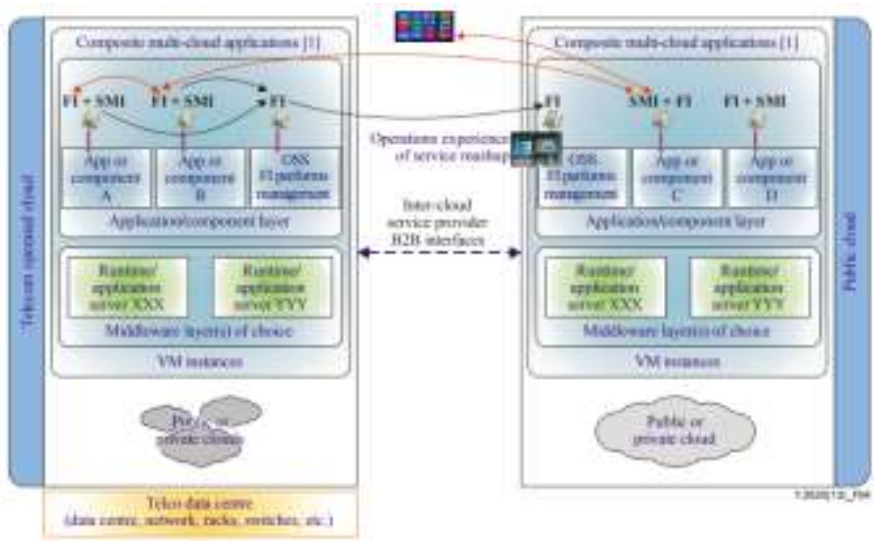

Fig. 3 Architectural vision for multi-cloud, multi-platform cloud management

During the work of the provider data center of the virtual BS system, the core subsystems and the virtual router are in a single logical space.

In fig. 3 we can see that at the level of middleware the Server XXX is present in every data center that participates in the inter-cloud computing infrastructure. The corresponding programs that activate the provider functional blocks are performed at the application and component level.

To ensure the operation of a mobile network using virtualization technology, it is necessary to provide a distributed structure of data centers, organized in a single virtual space. It must include deployed logical elements of the mobile service network, process management and flow allocation carried out by the orchestrator (fig. 4).

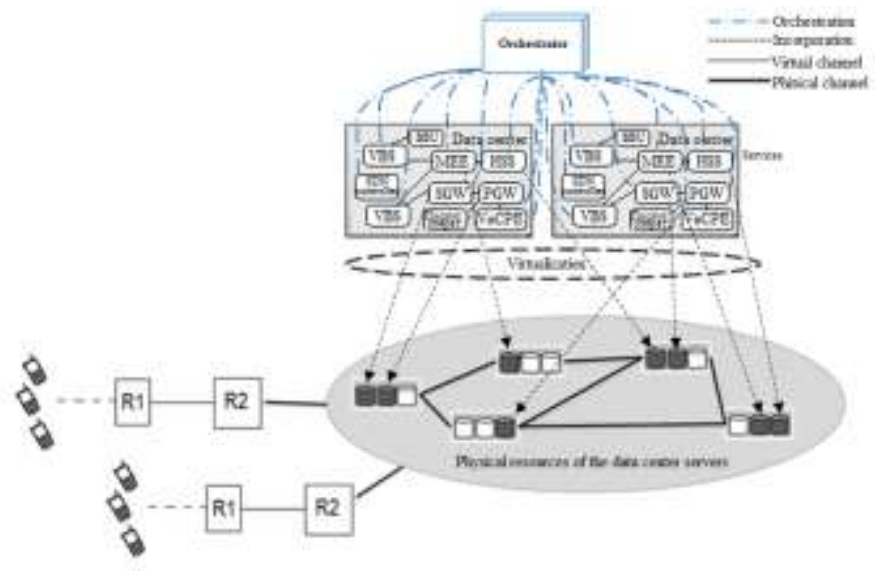

Fig. 4 Organization of service in new generation networks

The work of the new mobile operator networks is currently in active development of scientists around the world. The efficiency of service of end users depends on the effective organization of performance of calculations of function blocks of functional blocks.
У мережах наведених на Рис. 1 ефективність обслуговування абонентів залежить від ефективності організації роботи дата центра. У даному архітектурному рішенні під дата центром розуміється складана організаційно-технічна сукупність обчислювальних та телекомунікаційних системи які забезпечують безперебійну роботу інфраструктури NFV. Ефективність роботи дата центру залежить:

- від вибору фізичних дата центів, які увійдуть до складу розподіленої структури дата центрів;

- від того, як буде вирішено питання з розміщенням мережевих функцій у інфраструктурі розподілених дата центрів;

- від організації потоків між віртуалізованими сутностями;

- від виділення ресурсів для обслуговування віртуалізованих сутностей.

У подальших роботах будуть досліджуватися особливості ефективної роботи мобільних мереж 5-го покоління, та способи забезпечення показиників якості обслуговування кінцевих користувачів.

\section{CONCLUSION}

Функціонування сучасного інформаційнотелекомунікаційного середовища можна охарактеризувати як роботу складної системи, що обслуговує різні типи сервісів, які надаються не лише кінцевим абонентам, але й програмнокерованим автоматизованим системам, забезпечується різнорідним обладнанням, робота якого суттєво залежить від програмного забезпечення систем керування процесом обслуговування. Системи керування процесом обслуговування сервісів набувають все більшого розвитку. Наразі для забезпечення процесу керування розробляються стандарти, моделі та підходи із застосуванням технології хмарних обчислень $[2,3,4,5]$. При трансформації телекомунікаційних систем у інформаційно-телекомунікаційні з використанням хмарних сервісів виникає необхідність у нових моедлях та методах організації ефективної роботи інформаційнотелекомунікаційного середовища відповідно до вимог та особливостей процесу обслуговування ТС-гібридних сервісів.

\section{REFERENCES}

[1] J. ITU-T Y.3520 Telecommunication standardization sector of ITU $(06 / 2013)$ / Series Y: Global information infrastructure, internet protocol aspects and next-generation networks.

[2] Larysa G. et al. Managing of incoming stream applications in online charging system //Telecommunications (BIHTEL), 2014 X International Symposium on. - IEEE, 2014. - C. 1-6.

[3] Mariia Skulysh. The method of resources involvement scheduling based on the long-term statistics ensuring quality and performance parameters //Radio Electronics \& Info Communications (UkrMiCo), 2017 International Conference.

[4] Globa L. Method for resource allocation of virtualized network functions in hybrid environment / L. Globa, M. Skulysh, S. Sulima // 
2016 IEEE International Black Sea Conference on Communications and Networking Pages: 1 - 5, DOI: 10.1109/BlackSeaCom.2016.7901546.

[5] Skulysh M., Klimovych O. Approach to virtualization of Evolved Packet Core Network Functions //Experience of Designing and Application of
CAD Systems in Microelectronics (CADSM), 2015 13th International Conference The. - IEEE, 2015. - C. 193-195. 